\title{
МОРФОМЕТРИЧНИЙ АНАЛІЗ ОСОБЛИВОСТЕЙ СТРУКТУРНОЇ ПЕРЕБУДОВИ АРТЕРІЙ КЛУБОВОЇ КИШКИ ПРИ ПОСТРЕЗЕКЦІЙНІЙ ПОРТАЛЬНІЙ ГІПЕРТЕНЗІЇ
}

\author{
๑Л. В. Татарчук, М. С. Гнатюк
}

ДВНз «Тернопільський державний медичний університет імені І. Я. Горбачевського МОз України»

РЕзюМЕ. Резекції великих об'ємів печінки нерідко ускладнюються пострезекційною портальною гіпертензією, яка призводить до венозною застою та структурних змін в органах портальної системи, ремоделювання їх артеріального русла. Особливості структурної перебудови останнього у клубовій кишці при пострезекційній портальній гіпертензії вивчені недостатньо.

Мета - морфометричне вивчення особливостей ремоделювання артерій клубової кишки при резекції різних об'ємів паренхіми печінки.

Матеріал і методи. Комплексом морфологічних методів досліджена клубова кишка 36 статевозрілих білих щурів-самців, які були поділені на 3 групи. 1 група нараховувала 12 інтактних тварин, 2-12 щурів, у яких було видалено 31,5 \% паренхіми печінки, 3-12 дослідних тварин після резекції 58,1 \% паренхіми печінки. Евтаназію дослідних тварин здійснювали кровопусканням в умовах тіопенталового наркозу через 1 місяць від початку експерименту. Із клубової кишки виготовляли гістологічні мікропрепарати. Проводили морфометрію артерій дрібного калібру (2650 мкм) клубової кишки, при якій вимірювали їх зовнішній, внутрішній діаметри, товщину медії та адвентиції, висоту ендотеліоцитів, діаметрїхядер, визначали індексВогенворта, ядерно-цитоплазматичні відношеннявендотеліоцитах та відносний об'єм ушкоджених ендотеліоцитів. Кількісні показники обробляли статистично.

Результати. Встановлено, що при резекції 31,5 \% паренхіми печінки досліджувані морфометричні показники змінювалися незначно. При видаленні 58,1 \% паренхіми печінки виявлена виражена структурна перебудова артерій дрібного калібру клубової кишки. Через місяць після видалення 58,1 \% паренхіми печінки зовнішній діаметр артерій дрібного калібру зріс на 2,1%, товщина медії - на 17,9\%, товщина адвентиції - на 7,3 \%, індекс Вогенворта - у 1,5 раза, вказуючи на істотне порушення пропускної спроможності досліджуваних судин. Просвіт артерій дрібного калібру при цьому з вираженою статистичною достовірністю (р<0,001) зменшився на 16,9 \%. Висота ендотеліоцитів даних судин виявилася зміненою на 12,6 \%, а діаметр ядер - на 7,0 \% (p<0,001). Нерівномірні диспропорційні зміни морфометричних параметрів ендотеліоцитів та їх ядер призводили до виражених змін відношень між ядром та цитоплазмою, що свідчило про порушення клітинного структурного гомеостазу. Ядерно-цитоплазматичні відношення в ендотеліоцитах досліджуваних артерій виявилися суттєво зміненими, а відносний об'єм ушкоджених ендотеліоцитів при цьому зріс у 23,4 раза. Наведене свідчить про виражене ремоделювання артерій клубової кишки при видаленні 58,1 \% паренхіми печінки, яке призводить до погіршання кровопостачання органа, гіпоксії, дистрофії, некробіозу клітин і тканин, а пізніше - до інфільтративних та склеротичних процесів.

Висновки. Видалення 58,1 \% паренхіми печінки у дослідних тварин ускладнюється пострезекційною портальною гіпертензією, венозним застоєм у басейні печінкової ворітної вени. Зміни гемодинаміки при резекції великих об'ємів печінки призводять до вираженої структурної перебудови артерій дрібного калібру клубової кишки, яка характеризується потовщенням їх стінки, звуженням просвіту, зростанням індексу Вогенворта, зниженням пропускної спроможності судин, ураженням ендотеліоцитів, ендотеліальною дисфункцією, погіршанням кровопостачання органа, гіпоксією, дистрофією, некробіозом клітин і тканин, клітинними інфільтратами, склерозуванням.

КлючовІ СлОВА: резекція печінки; клубова кишка; структура артерій; морфометрія.

Вступ. Відомо, що резекція печінки у сучасних хірургічних клініках виконується достатньо часто. Видалення великих об'ємів паренхіми печінки нерідко супроводжується виникненням пострезекційної портальної гіпертензії $[2,10]$, яка призводить до тяжких ускладнень: кровотечі $з$ варикозно розширених вен стравоходу і шлунка, прямої кишки, асциту, спленомегалії, вторинного гіперспленізму, паренхіматозної жовтяниці, портосистемної енцефалопатії, печінкової недостатності $[2,10,12]$. Пострезекційна портальна гіпертензія ускладнюється також структурною перебудовою органів басейну ворітної печінкової вени, а також ремоделюванням їх артеріального русла. Особливості структурної перебудови останнього у клубовій кишці при пострезекційній портальній гіпертензії вивчені недостатньо [4].

Мета - морфометричне вивчення особливостей ремоделювання артерій клубової кишки при резекції різних об'ємів паренхіми печінки.

Матеріал і методи дослідження. Дослідження виконані на 36 лабораторних статевозрілих білих щурах-самцях, які були поділені на 3 групи. 1 група нараховувала 12 інтактних дослідних тварин (контрольна), 2 - 12 тварин, яким видаляли ліву бокову частку печінки, що складало 31,5 \% ії паренхіми, 3 - 12 щурів після резекції лівої та правої бокових часток, тобто 58,1 \% паренхіми печінки. Через 1 місяць від початку досліду здійснювали евтаназію щурів кровопусканням в умо- 
Огляди літератури, оригінальні дослідження, погляд на проблему, ювілеї

вах тіопенталового наркозу. Усі маніпуляції та евтаназію щурів проводили з дотриманням основних принципів роботи з експериментальними тваринами у відповідності з положенням «Європейської конвенції про захист хребетних тварин, які використовуються для експериментальних та інших наукових цілей» (Страсбург, 1986 р.), «Загальних етичних принципів експериментів на тваринах», ухвалених Першим національним конгресом з біоетики (Київ, 2001 р.), а також Закону України "Про захист тварин від жорстокого поводження" (від 21.02.2006 р.) [5].

Вирізані шматочки із клубової кишки фіксували в 10 \% нейтральному розчині формаліну і після відповідного проведення через етилові спирти зростаючої концентрації заливали у парафінові блоки за загальноприйнятою методикою. Гістологічні зрізи товщиною 5-7 мкм після депарафінізації фарбували гематоксиліном-еозином, за ван-Гізон, Маллорі, Вейгертом, толуїдиновим синім [9]. Проводили морфометрію артерій дрібного калібру (26-50) мкм клубової кишки, які знаходяться у більшому функціональному напруженні, порівняно з артеріями більших розмірів, і першими реагують на гемодинамічні зміни $[3,11]$. При морфометрії артерій вимірювали їх зовнішній (ЗД) та внутрішній (ДВ) діаметри, товщини медії (ТМ) та адвентиції (ТА), висоту ендотеліоцитів (BE), діаметр їх ядер (ДЯЕ), визначали індекс Вогенворта (IB), ядерно-цитоплазматичні відношення в ендотеліоцитах (ЯЦВ) та відносний об'єм ушкоджених ендотеліоцитів (ВОУЕ) $[1,3,11]$. Морфометрію вказаних судин проводили за допомогою світлового мікроскопа "Olimpus BX-2" з цифровою відеокамерою та пакетом прикладних програм “Відео Тест 5,0" та "Відео розмір 5,0". Кількісні величини обробляли статистично. Обробка результатів виконана у відділі системних статистичних досліджень Тернопільського держав- ного медичного університету імені І. Я. Горбачевського в програмному пакеті Statsoft STATISTICA. Різницю між порівнюваними величинами визначали за критеріями Манна-Уітні та Стьюдента [6].

Результати й обговорення. Отримані морфометричні параметри артерій дрібного калібру клубової кишки представлені у таблиці 1. У результаті проведеного всестороннього аналізу наведених у вказаній таблиці даних встановлено, що через місяць після видалення 31,3 \% паренхіми печінки структура досліджуваних судин змінилася незначно. Так, зовнішній діаметр артерій дрібного калібру клубової кишки при цьому зріс всього на 0,8 \%, а внутрішній статистично достовірно $(p<0,05)$ зменшився на $4,8 \%$, порівняно 3 контрольними величинами. Через місяць після резекції лівої бокової частки печінки товщина медії вказаних артерій збільшилася на 5,1\% (р<0,05), а товщина адвентиції - всього на 1,0%. Виражено у даних експериментальних умовах змінився індекс Вогенворта артерій дрібного калібру клубової кишки. Виявлено, що вказаний морфометричний параметр зі значною статистично достовірною різницею ( $<<0,001)$ збільшився на $12,2 \%$, що свідчить про зниження пропускної спроможності досліджуваних судин $[3,11]$.

Висота ендотеліоцитів артерій дрібного калібру клубової кишки у 2 групі спостережень виявилася зменшеною на 3,2 \% $(p<0,05)$, порівняно 3 аналогічною контрольною величиною, діаметр ядер ендотеліоцитів при цьому не змінювався. Ядерно-цитоплазматичні відношення у досліджуваних клітинах також не змінювалися, вказуючи на стабільність структурного клітинного гомеостазу [8]. Відносний об'єм ушкоджених ендотеліоцитів у артеріях дрібного калібру при резекції 31,5 \% паренхіми печінки зріс у 2,1 раза за рахунок апоптично, дистрофічно та некробіотично змінених досліджуваних клітин.

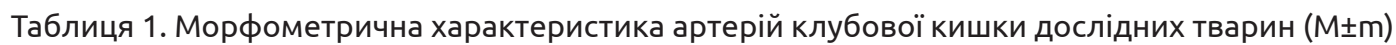

\begin{tabular}{|l|c|c|c|}
\hline \multicolumn{1}{|c|}{ Параметр } & \multicolumn{3}{c|}{ Група спостереження } \\
\hline ЗД, мкм & 1 & 2 & 3 \\
\hline ВД, мКм & $37,10 \pm 0,48$ & $37,40 \pm 0,51$ & $10,30 \pm 0,12^{* * *}$ \\
\hline ТМ, МКм & $12,40 \pm 0,15$ & $11,80 \pm 0,12^{*}$ & $9,20 \pm 0,09^{* * *}$ \\
\hline ТА, МКм & $7,80 \pm 0,09$ & $8,20 \pm 0,12^{*}$ & $6,20 \pm 0,03^{* * *}$ \\
\hline IВ, \% & $5,78 \pm 0,02$ & $5,84 \pm 0,04$ & $1353,90 \pm 20,4^{* * *}$ \\
\hline ВЕ, МКМ & $895,30 \pm 10,80$ & $1004,6 \pm 14,1^{* * *}$ & $5,20 \pm 0,06^{* * *}$ \\
\hline ДЯЕ, МКм & $5,95 \pm 0,06$ & $5,76 \pm 0,05^{*}$ & $2,92 \pm 0,05^{* *}$ \\
\hline ЯЦВ & $3,14 \pm 0,03$ & $3,06 \pm 0,05$ & $0,316 \pm 0,003^{* * *}$ \\
\hline ВОУЕ, \% & $0,278 \pm 0,003$ & $0,284 \pm 0,004$ & $50,30 \pm 0,51^{* * *}$ \\
\hline
\end{tabular}

Примітки: $1 .{ }^{*}-$ p<0,05; 2. ** - p<0,01; 3. *** - p<0,001 порівняно 31 групою спостережень. 
Огляди літератури, оригінальні дослідження, погляд на проблему, ювілеї

При резекції 58,1 \% паренхіми печінки досліджувані морфометричні параметри артерій дрібного калібру клубової кишки змінювалися більш виражено, порівняно з наведеними попередніми кількісними морфологічними показниками. Так, зовнішній діаметр досліджуваних судин збільшився на $2,1 \%$, а внутрішній їх діаметр з високою статистично достовірною різницею $(p<0,001)$ зменшився на 16,9\%. Товщини медії та адвентиції вказаних артерій з високим ступенем статистичної достовірності $(p<0,001)$ збільшилися відповідно на 17,9 та 7,3 \%. Індекс Вогенворта артерій дрі6ного калібру клубової кишки в умовах досліджуваного експерименту дорівнював $(1353,9 \pm 20,4) \%$. Наведений морфометричний параметр статистично достовірно $(p<0,001)$ відрізнявся від аналогічного контрольного і перевищував його у 1,5 раза. Потовщення стінки артерій, звуження їх просвіту, зростаня індексу Вогенворта свідчили про виражене зниження пропускної спроможності досліджуваних судин та погіршання кровопостачання органа $[3,11]$.

Висота ендотеліоцитів досліджуваних судин в умовах даного експерименту з вираженою статистично достовірною різницею $(p<0,001)$ зменшилася на 12,6\%, діаметр їх ядер - на 7,0\%. Суттєво змінилися при цьому ядерно-цитоплазматичні відношення у ендотеліоцитах дрібних артерій клубової кишки, вони дорівнювали $(0,316 \pm 0,003)$. Наведений морфометричний параметр статистично достовірно $(p<0,001)$ відрізнявся від аналогічного контрольного показника $(0,278 \pm 0,003)$ і перевищував його на $13,7 \%$, що свідчить про виражене порушення структурного клітинного гомеостазу [8]. Відносний об'єм ушкоджених ендотеліоцитів зріс при цьому на 23,4 \%.

При світлооптичному дослідженні мікропрепаратів стінки клубової кишки спостерігали виражені судинні розлади, набряки строми, осередки дистрофічно, некробіотично, апоптично змінених епітеліоцитів, вогнищеві інфільтрати та розростання сполучної тканини. Відмічали також набряк ендотеліоцитів, їх дистрофію, некробіоз, десквамацію та проліферацію. Останнє свідчило про наявність гіпоксії. Виявили також просякання мем6ран ендотеліоцитів, судинної стінки білками плазми. У деяких досліджуваних судинах спостерігали осередки фібриноїдного набряку та некрозу, що свідчить про виражене їх пошкодження. Виявляли також виражені судинні розлади, які характеризувалися повнокров'ям переважно венозних судин. У венозній ланці гемомікроциркуляторного русла спостерігали їх розширення, повнокров'я, стази, тромбози, осередки діапедезних крововиливів. Описані вище зміни у венозному руслі клубової кишки підтверджують наявність пострезек- ційної портальної гіпертензії, до якої призвело видалення 58,1 \% паренхіми печінки.

Наведене також свідчить, що видалення значного об'єму паренхіми печінки та ії судинного русла створює труднощі для повноцінного венозного дренажу з органів басейну ворітної печінкової вени. Венозна мікрогемокапіляропатія призводить до виражених трофічних порушень у навколишніх тканинах клубової кишки у вигляді дистрофічних, некробіотичних, апоптичних змін епітеліоцитів, ендотеліоцитів, стромальних структур, інфільтрації, а у віддалений період-до склерозування. Значну роль в описаних патологічних змінах клубової кишки відіграє структурна перебудова ії артеріального русла, при якій погіршується кровопостачання досліджуваного органа.

Виражені структурні зміни артерій дрібного калібру клубової кишки через місяць після резекції 58,1 \% паренхіми печінки свідчать про їхню особливу функціональну активність при перерозподілі кровотоку в умовах пострезекційної портальної гіпертензії. Потовщення стінки вказаних судин та звуження їх просвіту проходило за рахунок посилення тонусу, гіперплазії та гіпертрофії гладком'язових клітин. Одночасно спостерігали також підвищення тонусу бокових галужень артеріальних гілок. Виражена звивистість внутрішньої еластичної мембрани досліджуваних артерій свідчить про їх посилений тонус. Пошкодження значної кількості ендотеліоцитів $((50,30 \pm 0,51) \%)$ призводить до їхньої дисфункції, блокади NO-синтази, зменшення синтезу NO, активації процесів його деградації, посилення синтезу вазоконстрикторів: ендотеліну, ангіотензину-П, тромбоксану, простагландину НI, що посилювало спазм та звуження судин [7]. Описані структурні зміни артерій дрібного калібру клубової кишки суттєво впливали на регуляцію кровотоку в умовах пострезекційної портальної гіпертензії та забезпечували у даних патологічних умовах оптимальне кровопостачання органа.

Висновки. Видалення 58,1 \% паренхіми печінки у дослідних тварин ускладнюється пострезекційною портальною гіпертензією, венозним застоєм у басейні печінкової ворітної вени. Зміни гемодинаміки при резекції великих об'ємів печінки призводять до вираженої структурної перебудови артерій дрібного калібру клубової кишки, яка характеризується потовщенням їх стінки, звуженням просвіту, зростанням індексу Вогенворта, зниженням пропускної спроможності судин, ураженням ендотеліоцитів, ендотеліальною дисфункцією, погіршанням кровопостачання органа, гіпоксією, дистрофією, некробіозом клітин і тканин, клітинними інфільтратами, склерозуванням. 
Огляди літератури, оригінальні дослідження, погляд на проблему, ювілеї

Перспективи подальших досліджень. Все-

бічне адекватне вивчення закономірностей структурної перебудови артерій клубової кишки в умовах пострезекційної портальної гіпертензії дозволить суттєво розширити її діагностику, корекцію та профілактику.

\section{ЛІТЕРАТУРА}

1. Автандилов Г. Г. Основы количественной патологической анатомии / Г. Г. Автандилов. - М. : Медицина, 2002. -240 с.

2. Вишневський В. А. Сегментарные резекции, отдаленные результаты при злокачественных опухолях печени / В. А. Вишневский, М. Г. Ефанов, И. В. Казаков // Укр. журнал хірургії. - 2012. - № 1 (16). - С. 5-15.

3. Гнатюк М. С. Морфометрична оцінка вікових особливостей ремоделювання артерій дванадцятипалої кишки / М. С. Гнатюк, Л. В. Татарчук, М. В. Данів // Клінічна анатомія та оперативна хірургія. - 2009. - Т. 8, № 4. - С. 54-57.

4. Гнатюк М. С. Морфометрична оцінка особливостей ремоделювання структур дванадцятипалої кишки при резекції різних об'ємів печінки / М. С. Гнатюк, Л. В. Татарчук, О. Б. Ясіновський // Науковий вісник Ужгородського університету. Серія «Медицина». - 2016. Вип. 1 (53). - С. 92-95.

5. Загальні етичні принципи експериментів на тваринах // Ендокринологія. - 2003. - Т. 8, № 1. - С. 142-145.

6. Лапач С. Н. Статистические методы в медико-биологических исследованиях Excell / С. Н. Лапач, А. В. Губенко, П. Н. Бабич. - К. : Морион, 2001. - 410 с.

\section{REFERENCES}

1. Avtadnilov, G.G. (2002). Osnovy kolichestvennoy patologicheskoy anatomii [Basis of quantitative pathological anatomy]. Moscow: Meditsyna [in Russian].

2. Vishnevskiy, V.A., Yefanov, M.G. \& Kazakov, I.V. (2012). Segmentarnyye rezektsyi, otdalennyye rezultaty pri zlokachestvennykh opukholyakh pecheni [Segmentar resections, long-term results in malignant liver tumors]. Ukr. Zhurnal Khirurgii - Ukrainian Journal of Surgery, 1 (16), 5-15 [in Ukrainian].

3. Hnatiuk, M.S., Tatarchuk, L.V. \& Daniv, M.V. (2009). Morfometrychna otsinka vikovykh osoblyvostei remodeliuvannia arterii dvanadtsiatypaloi kyshky [Morphometric evaluation of the features of remodeling arteries of duodenum]. Klinichna anatomiia ta operatyvna khirurhiia Clinical Anatomy and Operative Surgery, 8, 4, 54-57 [in Ukrainian].

4. Hnatiuk, M.S., Tatarchuk, L.V. \& Yasinovskyi, O.B. (2016). Morfometrychna otsinka osoblyvostei remodeliuvania struktur dvanadtsiatypaloi kyshky pry rezektsii riznykh obiemiv pechinky [Morphometric evaluation of the features of remodeling of duodenal structures during resection of different volumes of the liver]. Naukovyi visnyk Uzhhorodskoho universytetu. Seriia "Medytsyna" - Scientific Herald of Uzhhorod University. Series "Medicine", 1 (49), 3-5 [in Ukrainian].
7. Макаров М. А. Роль дисфункции эндотелия и ригидности артерий в патогенезе хронической обструктивной болезни легких / М. А. Макаров, С. Н. Авдеев, А. Г. Чучалин // Терапевтический архив. - 2012. - № 3. - С. 74-80.

8. Саркисов Д. С. Структурне основы адаптации и компенсации нарушенных функций / Д. С. Саркисов. М. : Медицина, 1998. - 230 с.

9. Сорочинников А. Г. Гистологическая и микроскопическая техника / А. Г. Сорочинников, А. Е. Доросевич. - М. : Медицина, 2007. - 448 с.

10. Основные осложнения обширных резекций печени и пути их предупреждения / В. Д. Федоров, В. А. Вишневский, Н. А. Назаренко [и др.] // Бюлл. сибирской медицины. - 2007. - № 4. - С. 16-24.

11. Шорманов С. В. Гистологические и ультраструктурные изменения печени при экспериментальном стенозе легочного ствола на стадии декомпенсации / С. В. Шорманов, С. В. Куликов // Морфология. - 2010. № 3. - C. 46-50.

12. Nanashima A. A modified grading system for posthepatectomy metastatic liver cancer originating form colorectal carcinoma / A. Nanashima, Y. Sumida, T. Abo // J. Surg. Oncol. - 2008. - No. 98. - P. 363-370.

5. (2003). Zahalni etychni pryntsypy eksperymentiv na tvarynakh [General ethical principles of experiments on animals]. Endokrynolohiia - Endocrinology, 8, 1, 142-145 [in Ukrainian].

6. Lapach, S.N., Gubenko, A.V. \& Babich, P.N. (2001). Statistichieskiie metody $v$ mediko-biologicheskikh issledovaniyakh Excell [Statistical methods in medicobiological investigations Excell]. Kyiv: Morion [in Russian].

7. Makarov M.A., Avdieiev, S.H. \& Chuchalin A.G. (2012). Rol disfunktsyi endoteliya i regidnosti arteriy v patogeneze khronicheskoy obstruktivnoy bolezni legkikh [Role of endothelial cell dysfunction in medical and biological investigation]. Terapevticheskiy arkhiv-Theraputical Archive, 3, 74-80 [in Russian].

8. Sarkisov, D.S. (1998). Strukturnye osnovy adaptatsyi i kompensatsyi narushennykh funktsyy [Structural basis adaptation and compensation damage function]. Moscow: Meditsina [in Russian].

9. Sorochinnikov A.G. \& Dorosevich A.Ye. (2007). Gistologichieskaya i mikroskopicheskaya tekhnika [Histological and microscopic equipments]. Moscow: Meditsyna [in Russian].

10. Fedorov, V.D., Vishnevskiy, V.A. \& Nazarenko, N.A. (2007). Osnovnye oslozhneniya obshyrnykh rezektsyy pecheni i puti ikh preduprezhdeniya [The main complications of 
Огляди літератури, оригінальні дослідження, погляд на проблему, ювілеї

extensive liver resections and ways to prevent them]. Biull. Sibirskoy meditsyny - Bulletin of Siberian Medicine, 4, 16-24 [in Russian].

11. Shormanov, S.V. \& Kulikov, S.V. (2010). Gistologichieskiye i ultrastrukturnye izmineniya pecheni pri ekspierimentalnom stenoze legochnogo stvola na stadii dekompensatsyi [Histological and ultrastructural changes at experimental stenosis of pulmonary trunk at insufficiency]. Mofrologiya - Morphology, 3, 46-50 [in Russian].

12. Nanashima, A., Sumida, Y. \& Abo, T. (2008). A modified grading system for post-hepatectomy metastatic liver cancer originating form colorectal carcinoma. J. Surg. Oncol., 98, 363-370.

\title{
МОРФОМЕТРИЧЕСКИЙ АНАЛИЗ ОСОБЕННОСТЕЙ СТРУКТУРНОЙ ПЕРЕСТРОЙКИ АРТЕРИЙ ПОДВЗДОШНОЙ КИШКИ ПРИ ПОСТРЕЗЕКЦИОННОЙ ПОРТАЛЬНОЙ ГИПЕРТЕНЗИИ
}

\author{
๑Л. В. Татарчук, М. С. Гнатюк
}

\section{ГВУз «Тернопольский государственный медицинский университет имени И. Я. Горбачевского} МЗ Украины»

РЕЗЮМЕ. Резекции больших объемов печени нередко осложняются пострезекционной портальной гипертензией, которая приводит к венозному застою и структурным изменениям в органах портальной системы, ремоделированию их артериального русла. Особенности структурной перестройки последнего в подвздошной кишке при пострезекционной портальной гипертензии изучены недостаточно.

Цель - морфометрическое изучение особенностей ремоделировання артерий подвздошной кишки при резекции разных объемов паренхимы печени.

Материал и методы. Комплексом морфологических методов исследована подвздошная кишка 36 половозрелых белых крыс-самцов, которые были поделены на 3 группы. 1 группа насчитывала 12 интактных животных, 2 - 12 крыс, у которых было удалено 31,5 \% паренхимы печени, 3 - 12 исследуемых животных после резекции 58,1 \% паренхимы печени. Эвтаназия крыс осуществлялась кровопусканием в условиях тиопенталового наркоза через 1 месяц от начала эксперимента. Из подвздошной кишки изготовляли гистологические микропрепараты. Проводили морфометрию артерий мелкого калибра (26-50 мкм) подвздошной кишки, при которой измеряли их внешний, внутренний диаметры, толщину медии, адвентиции, высоту эндотелиоцитов, диаметр их ядер, определяли индекс Вогенворта, ядерно-цитоплазматические отношення в эндотелиоцитах и относительный объем поврежденных эндотелиоцитов. Количественные показатели обрабатывали статистически.

Результаты. Выявлено, что при резекции 31,5 \% паренхимы печени исследуемые морфометрические показатели изменялись незначительно. При удалении 58,1 \% паренхимы печени выявлена выраженная структурная перестройка артерий мелкого калибра подвздошной кишки. Через месяц после удаления 58,1 \% паренхимы печени внешний диаметр артерий мелкого калибра увеличился на 2,1\%, толщина медии - на 17,9 \%, толщина адвентиции - на 7,3 \%, индекс Вогенворта - в 1,5 раза, указывая на существенное нарушение пропускной спосо6ности исследуемых сосудов. Просвет артерий мелкого калибра при этом с вираженной статистической достоверностью ( $<2,001)$ уменьшился на 16,9 \%. Высота эндотелиоцитов этих сосудов была изменена на 12,6 \%, а их ядер - на 7,0 \% (р<0,001). Неравномерные, диспропорциональные изменения морфометрических параметров эндотелиоцитов и их ядер приводили к выраженным нарушениям соотношений между ядром и цитоплазмой, что свидетельствовало об изменениях клеточного структурного гомеостаза. Ядерно-цитоплазматические отношения в эндотелиоцитах исследуемых артерий существенно изменялись, а относительный объем поврежденных эндотелиоцитов при этом увеличился у 23,4 раза. Описанное свидетельствует о выраженном ремоделировании артерий подвздошной кишки при удалении 58,1 \% паренхимы печени, которое приводит к ухудшению кровоснабжения органа, гипоксии, дистрофии, некробиозу клеток тканей, а позднее - к инфильтративным и склеротическим процессам.

Выводы. Удаление 58,1 \% паренхимы печени у исследуемых животных осложняется пострезекционной портальной гипертензией, венозным застоем в бассейне печеночной воротной вены. Изменения гемодинамики при резекции больших объемов печени приводят к выраженной структурной перестройке артерий мелкого калибра подвздошной кишки, которая характеризуется утолщением их стенки, сужением просвета, увеличением индекса Вогенворта, снижением пропускной возможности сосудов, повреждением эндотелиоцитов, эндотелиальной дисфункцией, ухудшением кровоснабжения органа, гипоксией, дистрофией, некробиозом клеток тканей, клеточными нфильтратами, склерозированием.

КЛЮЧЕВЫЕ СЛОВА: резекция печени; подвздошная кишка; структура артерий; морфометрия. 


\section{Огляди літератури, оригінальні дослідження, погляд на проблему, ювілеї}

\section{MORPHOMETRICAL EVALUATION OF PECULIARITIES OF STRUCTURAL RECONSTRUCTION ARTERIES OF ILEUM AT POSTRESECTION PORTAL HYPERTENSION}

\section{Horbachevsky Ternopil State Medical University}

SUMMARY. The resections of large volumes of the liver leads to postresection portal hypertension that results is structural-functional changes in the organs of portal vena system. Features of remodeling arteries of ileum in the conditions of postresection portal hypertension are insufficiently studied.

The aim - morphometrical methods to study the features of remodeling of the arteries of the ileum at resection of different volumes of liver parenchyma.

Material and Methods. The complex of morphological methods examined the ileum of 36 sexually mature white male rats, which were divided into 3 groups. The group 1 consisted of 12 intact animals, $2-12$ rats, in which $31.5 \%$ of liver parenchyma was removed, 3 - 12 animals after resection $58.1 \%$ of liver parenchyma. Euthanasia of experimental animals was carried out by bloodletting in conditions of thiopental anesthesia 1 month after the beginning of the experiment. Histological preparations were made from the ileum. The morphometry of arteries of small caliber (26-50) microns of ileum was measured, in which their external and internal diameters, the thickness of the media and adventitia, the height of the endothelial cells, the diameter of their nuclei were determined, the Wogenworth index, the nuclearcytoplasmic ratios in the endothelial cells and the relative volume damaged endothelial cells. Quantitative indicators were processed statistically.

Results and Discussion. It was established that resection of $31.5 \%$ of liver parenchyma morphometric indices changed slightly. At removal $58.1 \%$ of parenchyma of the liver revealed a marked structural rearrangement of small arteries of the ileum. A month after the removal of $58.1 \%$ of the liver parenchyma, the outer diameter of the arteries of small caliber increased by $2.1 \%$, the thickness of the media - by $17.9 \%$, adventitia - by $7.3 \%$, the Vogenworts index - by 1.5 times, indicating on a significant violation of the throughput of the examined vessels. The inner diameter of arteries of small caliber with a pronounced statistical significance $(p<0.001)$ decreased by $16.9 \%$. The height of endothelial cells in these vessels was changed by $12.6 \%$, and their nuclei - by $7.0 \%(p<0.001)$. Non-uniform, disproportional changes in morphometric parameters of endothelial cells and their nuclei led to marked violations of the relationship between the nucleus and cytoplasm, indicating changes in cellular structural homeostasis. Nuclear cytoplasmic ratios in endothelial cells of investigated arteries were significantly disturbed, and the relative volume of damaged endothelial cells increased by 23.4 times. The presented evidence shows a pronounced remodeling arteries of the ileum in removing $58.1 \%$ of liver parenchyma, which leads to deterioration o blood supply to the organ, hypoxia, dystrophy, necrobiosis of cells and tissues, and later infiltrative and sclerotic processes.

Conclusions. Removal of $58.1 \%$ of liver parenchyma in experimental animals is complicated by postresection portal hypertension, venous stasis in the basin of the hepatic portal vein. Changes in hemodynamics after resection of large volumes of the liver lead to a pronounced structural rearrangement of the arteries small caliber of the ileum, characterized by thickening of their walls, narrowing of the lumen, growth of the Vogenworth index, decreased vascular capacity, endothelial cell damage, endothelial dysfunction, deterioration of blood supply to the organ, hypoxia, dystrophy, necrobiosis of cells and tissues, cell infiltrates, and sclerosis.

KEY WORDS: resection of the liver; ileum; artery structure; morphometry. 